\title{
An evaluation and analysis framework of integration policies as exemplified by foreigner integration policies - the experiences of selected European states
}

\author{
Ramy ewaluacji i analizy polityki publicznej \\ na przykładzie polityki integracji cudzoziemców - \\ wybrane doświadczenia europejskie
}

\section{Agnieszka Kulesa*}

\begin{abstract}
The subject of the considerations undertaken in the article is evaluation and analysis of integration policy, i.e. the one that concerns the integration of foreigners. Integration is understood as a dynamic, two-way process of mutual accommodation by all immigrants and residents of the European Union Member States (EU MS). The article aims at deepening the reflection on what it means to evaluate and analyse the integration policy defined this way as well as presenting the attempts to develop relevant frameworks in selected EU Member States.
\end{abstract}

\begin{abstract}
Abstrakt
Przedmiotem rozważań podjętych w artykule jest ewaluacja i analiza polityki integracyjnej, czyli takiej, która dotyczy integracji cudzoziemców. Ta ostatnia rozumiana jest jako proces dynamicznego, dwukierunkowego i wzajemnego dostosowania migrantów oraz osób zamieszkałych na terenie państw członkowskich Unii Europejskiej (UE). Celem autorki artykułu jest pogłębienie refleksji dotyczącej tego, czym jest ewaluacja i analiza tak rozumianej polityki integracyjnej oraz przedstawienie prób wypracowania ich ram w wybranych państwach UE.
\end{abstract}

* Warsaw School of Economics; (e-mail: aga.kulesa@gmail.com); 0003-2895-102X. 
Key words: evaluation of integration policy, analysis of integration policy, integration of foreigners, integration policy
Słowa kluczowe: ewaluacja polityki integracyjnej, analiza polityki integracyjnej, integracja cudzoziemców, polityka integracyjna

\section{Introduction}

As the interest in the migration policy in Poland has increased after 2015, public debates devote more attention to immigrant integration as well. The analysed issues concern the essence and goal of that process, the effectiveness of the current actions and suggested future solutions. At the same time, the solutions applied thus far have not undergone any critical, systematic and planned assessment which could form a solid basis for developing possible recommendations of changes. Public authorities reduce policy efficacy to the accomplishment of the financial aspect of the tasks scheduled for a given year. Such approach by no means meets the criteria of a reliable evaluation and analysis of integration policies.

Integration is an open and ambiguous concept. According to Rinus Penninx, the integration of foreigners is "the process of becoming an accepted part of society," while the European Union (EU), in line with the Common Basic Principles for Immigrant Integration Policy (2004), views integration as "a dynamic, two-way process of mutual accommodation by all immigrants and residents of Member States." ${ }^{2}$ An integration policy is one which leads to integration.

The article aims at deepening the reflection on what it means to evaluate and analyse an integration policy as well as presenting the attempts to develop relevant frameworks in selected EU Member States. To achieve this goal, I will draw on the achievements of researchers from Poland and abroad who deal with the issue of public policy evaluation and analysis as well as the application of scientific knowledge by political decision makers to integration policies. ${ }^{3}$ I will

${ }^{1}$ R. Peninnx: Decentralizacja polityk integracyjnych. Zarzadzanie migracja $w$ miastach, regionach $i$ społecznościach lokalnych. W: Laboratoria integracji. Obserwacje i notatki praktyczne. Red. M. BIENIECKI, M. Pawlak. Gliwice 2010, p. 23.

${ }^{2}$ Council of the European Union, Press Release, 2618th Council Meeting, Justice and Home Affairs, 14615/04 (Presse 321), Brussels, 19 November 2004 - http://www.consilium. europa.eu/ueDocs/cms_Data/docs/pressData/en/jha/82745.pdf,p. 17 (accessed: 6.02.2019).

M. PAWLAK: Wykorzystanie wiedzy naukowej $i$ eksperckiej $w$ ksztattowaniu polityki integracji migrantów w Polsce po 2004 roku. "Normy, Dewiacje i Kontrola Społeczna" 2012, nr 13, p. 105-138; Idem: Polityki publiczne wobec migracji. W: Nauki o polityce publicznej. Monografia dyscypliny. Red. J. Kwaśniewski. Warszawa 2017, p. 288-311; M. SAKowicz: Analiza polityki publicznej z wykorzystaniem modelu cyklu działań publicznych. W: Polityka 
also analyse the significant legal acts of the European Union. Consequently, the first part of the article will be devoted to evaluation and analysis of public policies in general and integration policies in particular; then, I will discuss integration policy evaluation and analysis in the EU; finally, I will present examples of integration policy evaluation in Great Britain, Germany and Poland.

\section{Evaluation and analysis of public policies}

Public policy is "a field of systemic, ordered actions taken by the state and its citizens which stem from generated and objectivised knowledge and aim at solving key collective problems." ${ }^{, 4}$ Public policy is also sometimes defined as "an intended and purposeful process of accomplishing the assumptions stemming from decisions made by public authorities which aims at solving public problems, supplying public goods and meeting social needs." Politics is an activity without a defined end; therefore, it constitutes a challenge in evaluation and analysis. However, one must remember that public policy forms a whole which consists of objectives (strategy, mission) as well as plans of their accomplishment (programme) and implementation (project). Strategies, programmes and projects are defined in time, so their examination, evaluation and analysis is easier.

To define the subject of the undertaken considerations more precisely, one must explain the difference between the three abovementioned activities. Ryszard Szarfenberg writes: "Examination aims at discovering and describing empirical facts as well as testing the hypotheses which state such facts or the connections between them. Evaluation consists of systematic investigations aimed at assessing the quality and value of the subject... Analysis focuses on formulating recommendations and indications concerning the subject." ${ }^{\prime 6}$ Therefore,

publiczna. Teoria. Jakość. Dobre praktyki. Red. J. OsıńsKi, I. ZawiślańsKa. Warszawa 2016, p. 39-60; P. Scholten: Framing Immigrant Integration: Dutch Research-Policy Dialogues in Comparative Perspective. Amsterdam 2011; P. Scholten, H. Entzinger, R. Penninx: Research-Policy Dialogues on Migrant Integration in Europe. A Conceptual Framework and Key Questions. In: Integrating Immigrants in Europe. Research-Policy Dialogues. Eds. P. Scholten, H. Entzinger, R. Penninx, S. Verbeek. Dordrecht 2015; Y. Surel: The Role of Cognitive and Normative Frames in Policy-making. "Journal of European Public Policy" 2000, Vol. 7, Issue 4, p. 495-512; R. SzARFEnBERG: Ewaluacja i analiza polityki społecznej. W: Polityka społeczna. Podręcznik akademicki. Red. G. Firlit-Fresnak, M. Szylko-SkoczNY. Warszawa 2008, p. 127-141; A. ZybaŁa: Polityki publiczne. Warszawa 2012.

${ }^{4}$ A. Zybala: Polityki publiczne..., p. 13.

${ }^{5}$ M. SAKowicz: Analiza polityki publicznej..., p. 41.

${ }^{6}$ R. Szarfenberg: Ewaluacja i analiza..., p. 127. 
evaluation is an assessing activity going beyond the scope of examination, while analysis additionally includes the practical aspect of the examination and evaluation subject. Accordingly, evaluation is a defined and planned activity which meets the objectiveness criteria and is governed by scientific discipline in the scope of the applied methodology of information collection and assessment. Analysis produces recommendations the justification of which "requires at least an evaluation of alternative solutions and comparison of their results."

Evaluation and analysis play a special role in so-called procedural approach to public actions, according to which a cycle of public actions spans at least three stages: (1) identification of the problem and assessing the legitimacy of a public intervention aimed at solving it; (2) defining the principles and objectives of the projected public policy; and (3) determining the instruments and resources necessary to achieve the assumed objectives and assessing their legitimacy. ${ }^{8}$ At the same time, evaluation and analysis support the building of evidence-based policy. Karol Olejniczak and Stanisław Mazur remark that such conception assumes the use of "high-quality information, data and knowledge coming from various sources: knowledge of experts, domestic and international research, statistics, stakeholders' opinions, consultation and evaluation of the already accomplished policies."

Evaluation is based on the use of previously defined assessment criteria and the resulting indicators. Szarfenberg indicates that "the source of assessment criteria is values"10 and the universal evaluation values include effectiveness, efficacy ${ }^{11}$, accuracy, usefulness, durability and coherence. The policy (strategy, programme or project) assessment obtained via evaluation may be the source of legitimisation, demonstration or confirmation of accountability and justification of the undertaken public actions. ${ }^{12}$ It can also be used to delay or "blur" unwanted reforms or introduce political control over other statutory authorities. ${ }^{13}$ In this context it is important to determine who initiates the evaluation process and controls whether, how and to what extent its results will be used. One must remember that "the state is not a homogeneous player in the public policy be-

${ }^{7}$ Ibidem, p. 128.

${ }^{8}$ M. SAKowicz: Analiza polityki publicznej..., p. 42, 51-54.

9 One must note here that evaluation concerns not only "the already accomplished policies", but also projected ones (e.g. via assessing the regulation effects) and those being implemented at the moment. S. Mazur, K. Olejniczak: Rola organizacyjnego uczenia się we wspótczesnym zarządzaniu publicznym. W: Organizacje uczace się. Model dla administracji publicznej. Red. K. OlejniczaK. Warszawa 2012, p. 38.

${ }^{10}$ R. Szarfenberg: Ewaluacja i analiza..., p. 131.

${ }^{11}$ Effectiveness and efficacy are the main praxeological values.

12 J. Turnpenny, C.M. Radaelli, A. Jordan, K. Jacob: The Policy and Politics of Policy Appraisal: Emerging Trends and New Directions. "Journal of European Public Policy" 2009, Vol. 16, Issue 4, p. 641.

13 Ibidem, p. 642. 
cause its authorities accomplish various interests and strive for various goals." ${ }^{\prime 14}$ Representatives of scientific circles, analysts and experts whom governments may commission to carry out an evaluation also have their own interests and goals, whether conscious or not. In this context, carrying out an evaluation may mean that the evidence it produces might help one overcome the process of policy formulation based on interests instead of facts as well as integrate the cross-cutting issues and increase the cooperation among the players. In line with another viewpoint, an assessment may lead to the pluralisation of politics and public administration because it can constitute a starting point for opening new areas of public deliberations concerning various alternative options of public interventions. To sum up, both policy evaluation and analysis are manifestations of the political behaviour of institutions and other political players.

The question whether politics can be made more "rational" by applying analytical techniques and tools remains open. One issue related to that question is the use of scientific and expert knowledge by politics in general. This brings to mind another question: What do decision makers want - legitimisation or profit maximisation? It seems that knowledge can be used for various purposes symbolically, instrumentally or to provide explanation $s^{15}$ - and statutory authorities do not always act rationally.

In this context one should note that the end of the 20th century saw a turn in the Western research on public policy: researchers began to underline the influence of ideas, general principles, social norms, values and notions on social evolution and the functioning of the state. ${ }^{16}$ According to that approach, cognitive and normative elements play an important role in the way political players understand and explain the world. The analysis concerns, among others, the creation process and the role of cognitive and normative frames in formulating the assumptions of a public policy and its implementation. Those frames fulfil an integrating function in a given community. Moreover, since they create the world view and define lawful, legitimised practices, they seem dependent on the mechanisms of identity determination, power distribution and their ability to manage social tensions. ${ }^{17}$

Referring the above to the integration policy of a state, one must first highlight that evaluation and analysis should concern a certain desired final state: the integration of foreigners. The way the latter is defined depends first and foremost on political decision makers ${ }^{18}$ while the defining process itself is a manifestation of ruling - therefore, it is a political act. Second, one can expect

${ }_{14}$ M. Pawlak: Polityki publiczne wobec migracji..., p. 295.

15 M. PAWlaK: Wykorzystanie wiedzy naukowej i eksperckiej..., p. 105.

${ }^{16}$ Y. SUREL: The Role of Cognitive and Normative Frames..., p. 495.

17 Ibidem, p. 500.

${ }^{18}$ Science can simultaneously develop its own definitions of this concept - and this is what happens indeed. 
that an integration policy will be accomplished based on a specific strategy and as part of programme(s) and projects which will be examined, evaluated and analysed. One should stress that the situation where an integration policy is not related to any strategy, programme or implementation project may also stem from a thought-out political decision. However, this does not equal lack of politics: a purposeful omission is a political action, too. Third, an integration policy evaluation will be based on specific indicators ${ }^{19}$ and will concern both the policy accomplishment process itself and the achieved results. Fourth, one can distinguish between ex-ante, on-going and ex-post evaluation as well as external and internal evaluation also in the case of integration policies. Moreover, integration policies are influenced by the social and cultural norms and frames which dominate in a given community at a certain period.

\section{Evaluation and analysis of integration policies: The European union law and practice}

\section{Legal issues}

The issues related to the shaping and implementation of integration policies concerning foreigners residing in the territory of a given Member State belong to the competence of that MS. However, since the moment of signing the Treaty of Lisbon in 2007, according to par. 4 of Article 63a, "[the] European Parliament and the Council ... may establish measures to provide incentives and support for the action of Member States with a view to promoting the integration of third-country nationals residing legally in their territories, excluding any harmonisation of the laws and regulations of the Member States." ${ }^{20}$ Exercising this right, the European Commission (EC) published the Action Plan on the Integration of Third-Country Nationals (2016), ${ }^{21}$ in which it referred to the Common

${ }^{19}$ One can encounter single-criterion and multi-criteria (single-indicator and multi-indicator) evaluation.

20 Treaty of Lisbon amending the Treaty on European Union and the Treaty establishing the European Community (2007/C 306/01) - https://eur-lex.europa.eu/legal-content/PL/ TXT/HTML/?uri=CELEX:12007L/TXT\&from=EN (accessed: 6.02.2019).

${ }^{21}$ European Commission, Communication from the Commission to the European Parliament, the Council, the European Economic and Social Committee and the Committee of the Regions, Brussels, 7.6.2016, COM (2016) 377 final - https://ec.europa.eu/home-affairs sites/homeaffairs/files/what-we-do/policies/european-agenda-migration/proposal-1mplementa tion-package/docs/20160607/communication_action_plan_integration_third-country_nation als_en.pdf (accessed: 6.02.2019). 
Basic Principles for Immigrant Integration Policy (2004) 22 and the Common Agenda for the Integration of Third-Country Nationals, published by the EC in 2011. ${ }^{23}$ The Common Basic Principles place special emphasis on the integration of foreigners with the labour market, knowledge of the language spoken in the host state as well as education both of the immigrants themselves and their children residing with them in the target state of migration. Moreover, the document highlights, among other things, the necessity of providing immigrants with access to institutions, goods and services equal to the access possessed by the European Union citizens. It also underlines the importance of involving them in the democratic process. Furthermore, it stresses the necessity of developing evaluation objectives, indicators and mechanisms to adjust the integration policy, evaluate the integration progress and exchange information more effectively. ${ }^{24}$ The Common Agenda, in turn, states that "close cooperation between the different levels of governance is important to coordinate the provision, financing and evaluation of services" offered as part of the actions aimed at immigrant integration. ${ }^{25}$ It also refers to a pilot study by Eurostat entitled Indicators of Immigrant Integration ${ }^{26}$ and announces that the EC will apply the integration "indicators" determined in four areas: employment, education, social inclusion and active citizenship. ${ }^{27}$ Those indicators were supposed to be used for "monitoring the results of integration policies in order to increase the comparability of national experiences and reinforce the European learning process." 28

The Commission Plan of 2016 provides information on the challenges and barriers to integration as well as a list of key political priorities and integrationstrengthening tools. The political priorities include:

- measures taken before the immigrant leaves the country of origin / arrives at the target state of migration;

- education;

${ }^{22}$ Council of the European Union Press Release, 2618th Council Meeting, Justice and Home Affairs, 14615/04 (Presse 321), Brussels, 19 November 2004 - http://www.consilium. europa.eu/ueDocs/cms_Data/docs/pressData/en/jha/82745.pdf (accessed: 6.02.2019).

European Commission, Communication from the Commission to the European Parliament, the Council, the European Economic and Social Committee and the Committee of the Regions. European Agenda for the Integration of Third-Country Nationals, KOM/2011/0455 final - https://eur-lex.europa.eu/legal-content/PL/TXT/HTML/?uri=CELEX:52011DC0455 \&from=EN (accessed: 6.02.2019).

${ }^{24}$ The provision on evaluation is included in par. 19 of the Common Principles.

${ }^{25}$ Par. 2 "Improvement of multi-level cooperation".

${ }^{26}$ Eurostat: Indicators of Immigrant Integration. A Pilot Study. Eurostat Methodologies and Working Papers 2011 — https://ec.europa.eu/eurostat/documents/3888793/5849845/KS-RA11-009-EN.PDF/9dcc3b37-e3b6-4ce5-b910-b59348b7ee0c (accessed: 6.02.2019).

The indicators as such reflected the key integration areas expressed in the Common Principles.

${ }^{28}$ Eurostat: Indicators of Immigrant Integration... 
- integration into the labour market and access to vocational training;

- access to basic services (e.g. apartments, health care);

- active participation and social inclusion.

Concerning specific tools, the EC lists further support of coordination among the Member States (e.g. replacing the network of the National Contact Points on Integration with the European Integration Network, supporting the development of the European Migration Forum established to replace the European Integration Forum) and ensuring financing via a 2014-2020 long-term programme and specific funds (including the Asylum, Migration and Integration Fund). The Commission highlights in the document that it will continue developing the knowledge of integration results on the European level, including via monitoring its results on the local level in cooperation with the Member States and with the involvement of the Organisation for Economic Co-operation and Development (OECD) ${ }^{29}$ and cooperating more closely with other significant players such as the Fundamental Rights Agency (as part of the EU-MIDIS II project, among other things ${ }^{30}$ ).

In the historical perspective, the development of integration policies in the European Union Member States was related especially to public administration activity on the local level. However, the issue gradually became so important that at the beginning of the 21st century most European countries already possessed an integration policy. ${ }^{31}$ Concerning the policies directed at immigrants, the integration model presently dominates in the European Union Member States. ${ }^{32}$ At the same time, "the public interest in migration is so huge that politicians prefer to act according to their voters' common ideas about migration than scientific evidence when they develop public policies." ${ }^{33}$ The application of scientific and expert knowledge, if any, is increasingly often instrumental. Simultaneously, assimilationism and post-nationalism is becoming more noticeable among the basic frames defining immigrant integration as distinguished by Peter Scholten, i.e. assimilationism, multiculturalism, differentialism, universalism, transnationalism and post-nationalism. ${ }^{34}$

${ }^{29}$ In 2015, the OECD published a report entitled "Indicators of Immigrant Integration 2015 - Settling In", which resulted from the cooperation with the European Commission (Directorate-General for Migration and Home Affairs).

30 The project included a survey concerning discrimination which was conducted among immigrants and ethnic minority representatives in all the Member States. More information about the survey and its results is provided on the website of the Fundamental Rights Agency — http://fra.europa.eu/en/publication/2017/eumidis-ii-main-results (accessed: 6.02.2019).

31 P. Scholten, H. Entzinger, R. Penninx: Research-Policy Dialogues..., p. 1.

32 M. PaWlak: Polityki publiczne wobec migracji..., p. 291.

33 Ibidem, p. 303.

34 P. Scholten: Framing Immigrant Integration..., p. 38-42. 


\section{Evaluation and analysis attempts - selected examples}

The most important attempt at developing a universal mechanism of integration policy assessment i.a. in EU Member States remains the international project entitled "The Migrant Integration Policy Index" (MIPEX). ${ }^{35}$ The fourth and last edition of the project was co-financed using EU funds and implemented in the years 2013 - 2015. It was headed by the Barcelona Centre for International Affairs (CIDOB) and the Migration Policy Group (MPG) from Brussels. The main objectives of the project included:

1) identification and measurement of the results of integration, integration policies and other contextual factors influencing the efficacy of the policies;

2) verification of the access to rights and the possibility of taking advantage of the designed solutions and instruments by the real and potential beneficiaries of integration policies in key areas: employment, education, political participation, access to citizenship, family reunion, health, access to long-term residence and anti-discrimination actions;

3) collection and analysis of good-quality evaluations of the integration policy effects.

In the last edition of the MIPEX project, policy assessment was based on 167 indicators in the eight abovementioned areas. The examination has shown that the integration policies of the analysed states are on average ambivalent concerning granting the immigrants equal rights and possibilities and that the number of facilitations is only slightly higher than the number of obstacles on the way to full immigrant participation in the economic, social and political life. In general, immigrants face greater integration obstacles in the new target states of migration, while the bigger, older and wealthier states, including those traditionally viewed as immigration states, offer them greater facilitations and possibilities.

The evaluation as part of MIPEX was initiated and conducted by the scientists working in the abovementioned organisations. The application of its results by public decision makers of the individual EU Member States is debatable. Still, the administration in certain EU states, e.g. Great Britain and Germany, implements its own evaluation programmes.

Great Britain is a country with rich migration tradition which dates back to the British Empire. In comparison with other EU states with colonial past, that country experienced the largest influx of immigrants from the Commonwealth of Nations. One result of that process was the adoption of a multiculturalism

${ }^{35}$ See: http://www.mipex.eu (accessed: 6.02.2019). The project covered all the European Union Member States, Australia, Iceland, Japan, Canada, South Korea, New Zealand, Norway, United States of America, Switzerland and Turkey. 
policy. According to the MIPEX evaluation, the integration policy of Great Britain is currently considered as moderately favourable. ${ }^{36}$

The main player responsible for the integration policy in Great Britain is Home Office. In 2004, it ordered Alistair Ager and Alison Strang ${ }^{37}$ to develop indicators of integration concerning the integration of international protection beneficiaries. The researchers suggested 10 indicators grouped in four areas: $^{38}$

1) means and markers, which include employment, accommodation, education and health;

2) social bonds, which include social responsibilities inside the refugee community, social bridges ensuring the connection with other communities and social links with the institutions of power and impact;

3) facilitators, which include knowledge of language and culture as well as safety and stability;

4) foundation, which covers rights and citizenship.

The report by Ager and Strang remains one of the most readily used proposals of evaluation frames for the integration policy concerning international protection beneficiaries in Great Britain as well as one of the first such attempts on the EU scale.

Regarding Germany, one should note that the country has an immigration status, but foreigner integration was included in the immigration law relatively late, in 2005. Moreover, a coherent integration act entered into force in 2016 as a consequence of so-called migration and refugee crisis in 2015. Due to the political system of the country, the integration policy in Germany is also accomplished on the level of individual constituent states and cities. For example, Berlin (2010), North Rhine-Westphalia (2012) and Baden-Württemberg (2015) have adopted solutions aimed at supporting the integration efforts made on the federal level. One should note that the German integration policy (the individual integration actions and their effects) achieved a relatively good result in the evaluation conducted within the MIPEX project. ${ }^{39}$

The main player responsible for the integration policy in Germany on the federal level is the Federal Office for Migration and Refugees (BAMF). The Office regularly assesses the integration actions carried out, including i.a. questionnaires, satisfaction surveys and financing of external surveys. An example of the latter is a survey entitled "Selected Groups of Migrants in Germany" (RAM),

${ }^{36}$ See: http://www.mipex.eu/united-kingdom (accessed: 6.02.2019).

37 Their project was financed by the European Refugee Fund.

38 A. Ager, A. Strang: Indicators of Integration: Final Report. London 2004 - http:// webarchive.nationalarchives.gov.uk/20110218141321/http:/rds.homeoffice.gov.uk/rds/pdts04/ dpr28.pdf (accessed: 6.02.2019).

See: http://www.mipex.eu/germany (accessed: 6.02.2019). 
which was last carried out in the years 2006/2007.40 The survey analysed the situation of selected groups of immigrants in terms of education, employment and financial situation, family structure and linguistic skills as well as social integration. It also utilised the indicators concerning accommodation conditions, health, crime, culture and religion, naturalisation, attitude toward immigrants and xenophobia as well as identification and bond with the sending and host states. As field researchers indicate, the Office used the obtained knowledge, including scientific and expert knowledge, to legitimise its role as a competent organisation in the shaping of the integration policy. ${ }^{41}$

Attempts of expert evaluation of the integration policy concerning international protection beneficiaries are also made in Poland, where immigrant integration is a relatively new and narrow issue and therefore its shaping is largely influenced by drawing on the standards implemented in Western European countries. ${ }^{42}$ Poland does not currently possess a general strategy or programme concerning foreigner integration. The main group taking advantage of a dedicated programme are international protection beneficiaries. The non-governmental organisations which carry out their own evaluations of that programme point in particular at the insufficiency of the support in terms of its availability time and level. ${ }^{43}$ Studies regarding integration policy evaluation in general are also drafted; they point at specific integration barriers concerning access to the labour market, language learning and access to apartments. ${ }^{44}$

One must remark here that although the substance of the Polish integration policy has not been significantly altered since 2015, the relevant rhetoric of the actors responsible has changed. First and foremost, this means placing emphasis on different aspects of the migration policy in general and the resulting increased leaning toward protecting the "security interests" of the state (and not only its economic or social interests) demonstrated by the main authority responsible for the migration policy - the Ministry of the Interior and Administration (MSWiA). Consequently, not only the integration policy frame, but also the nature of integration actions may change. This is suggested by the government members' statements, such as the one uttered by the then Deputy Minister of the Interior and Administration Jakub Skiba in an interview conducted by "Biuletyn Migracyjny": "The [integration policy] model promoted by the previous government and adopted from the Western countries was as follows: let us

${ }^{40}$ The survey results are available in English on the following website - http://www. bamf.de/SharedDocs/Projekte/EN/DasBAMF/Forschung/Integration/repraesentativuntersu chung-2006-2007.html?nn=1448998 (accessed: 6.02.2019).

M. PAWLAK: Wykorzystanie wiedzy naukowej i eksperckiej..., p. 113.

42 Ibidem, p. 107.

43 J. Klavier, A. Pilat, D. Potkańska, A. Sitko: Local Responses to the Refugee Crisis. Reception and Integration. Warszawa 2016.

${ }^{44}$ Bieg przez plotki. Bariery na drodze do integracji migrantów w Polsce. Red. A. Mikulska, H. PAtzer. Warszawa 2012. 
introduce new elements into the society and put the emphasis on increasing the absorption capacity, i.e. on lowering the distrust level of the society toward the newcomers from abroad... We look at it pragmatically and reckon that such approach leads nowhere... In our opinion, successful integration means that the newcomers know and understand the culture of the host state." 45

Even though no general integration strategy exists and the MSWiA questions the purpose of the actions conducted thus far, Poland has been carrying out a project entitled "National Integration Evaluation Mechanism. Measuring and improving integration of beneficiaries of international protection"46 (NIEM) since 2015. The project is financed by the Asylum, Migration and Integration Fund and was directly included in the AMIF National Programme as a socalled specific action. The project leader is the Institute of Public Affairs and the consortium includes fifteen partner organisations (universities, think-tanks and non-governmental organisations) from various EU Member States, including the abovementioned CIDOB and MPG. The main objective of the project is to develop an evaluation mechanism for the integration policies directed at international protection beneficiaries, which is planned to be based on more than 150 indicators grouped into four main areas:

1) general conditions of integration;

2) the legal dimension of integration (residence, family reunion, access to citizenship);

3) the social and economic dimension of integration (accommodation, employment, vocational training and other training, health, social security);

4) the social and cultural dimension of integration (education of children, language learning and knowledge of the society, strengthening of the participation in the social and political life).

The project is scheduled to last till the end of 2020. If accomplished, it will provide a tool for both ex-post and on-going evaluation, i.e. facilitating evaluation, which aims at improving a programme (policy, project) and its accomplishment. The readiness and willingness of Polish and foreign administrations to use that tool remains an open issue.

\section{Conclusion}

No general mechanism of integration policy evaluation and analysis has been developed yet, neither on the EU scale nor in any Member State. One must re-

${ }^{45}$ R. Stefańska, M. Szulecka: "Pragmatycznie, a nie ideologicznie" - o polityce migracyjnej Polski. "Biuletyn Migracyjny” 2016, nr 55.

${ }^{46}$ See: http://www.forintegration.eu/(accessed: 6.02.2019). 
member that foreigner integration is a national competence. At the same time, various initiatives are taken on the national and supranational level to develop an integration policy evaluation tool which would facilitate integration policy analysis and introduction of appropriate corrections. The proposed solutions are based on a number of indicators and one can notice a tendency to extend their list systematically. Evaluation frame creation is often originated by the state, but evaluation and analytical actions are initiated also by other players such as nongovernmental organisations or academic circle representatives.

\section{Bibliography}

Ager A., Strang A.: Indicators of Integration: Final Report. Home Office Development and Practice Report 28, London 2004 - http://webarchive.nationalan chives.gov.uk/20110218141321/http:/rds.homeoffice.gov.uk/rds/pdfs04/dpr28.pdf (accessed: 6.02.2019).

Council of the European Union, Press Release, 2618th Council Meeting, Justice and Home Affairs, 14615/04 (Presse 321), Brussels, 19 November 2004 - http:// www.consilium.europa.eu/ueDocs/cms_Data/docs/pressData/en/jha/82745.pdf (accessed: 6.02.2019).

European Commission, Communication from the Commission to the European Parliament, the Council, the European Economic and Social Committee and the Committee of the Regions, Brussels, 7.6.2016, COM(2016) 377 final - https:// ec.europa.eu/home-affairs/sites/homeaffairs/files/what-we-do/policies/europd an-agenda-migration/proposal-implementation-package/docs/20160607/commu nication_action_plan_integration_third-country_nationals_en.pdf (accessed: 6.02.2019).

European Commission, Communication from the Commission to the European Parliament, the Council, the European Economic and Social Committee and the Committee of the Regions. European Agenda for the Integration of Third-Country Nationals, KOM/2011/0455 final - https://eur-lex.europa.eu/legal-content/ PL/TXT/HTML/?uri=CELEX:52011DC0455\&from=EN (accessed: 6.02.2019).

Eurostat: Indicators of Immigrant Integration. A Pilot Study. Eurostat Methodo logies and Working Papers 2011 - https://ec.europa.eu/eurostat/documents 3888793/5849845/KS-RA-11-009-EN.PDF/9dcc3b37-e3b6-4ce5-b910-b59348b7 ee0c (accessed: 6.02.2019).

Helsinki Foundation for Human Rights. Red. A. Mikulska, H. Patzer. Warszawa 2012.

Klavier J., Pilat A., Potkańska D., Sitko A.: Local Responses to the Refugee Crisis. Reception and Integration. Warszawa 2016.

Mazur S., K. OlejniCzaK K.: Rola organizacyjnego uczenia się we współczesnym zarzadzaniu publicznym. W: Organizacje uczace się. Model dla administracji publicznej. Red. K. OleJniczaK. Warszawa 2012. 
PaWlak M.: Polityki publiczne wobec migracji. W: Nauki o polityce publicznej: monografia dyscypliny. Red. J. KwAŚNIEWSKI. Warszawa 2017.

PAWLAK M.: Wykorzystanie wiedzy naukowej i eksperckiej w ksztaltowaniu polityki integracji migrantów w Polsce po 2004 roku. "Normy, Dewiacje i Kontrola Społeczna” 2012, nr 13.

PEnNinx R.: Decentralizacja polityk integracyjnych. Zarzadzanie migracja w miastach, regionach i społecznościach lokalnych. W: Laboratoria integracji. Obserwacje i notatki praktyczne. Red. M. BIENIECKI, M. PAWLAK. Gliwice 2010.

SAKowicz M.: Analiza polityki publicznej z wykorzystaniem modelu cyklu działań publicznych. W: Polityka publiczna. Teoria. Jakość. Dobre praktyki. Red. J. OsIŃsKi, I. ZaWiślańsKa. Warszawa 2016.

Scholten P., Entzinger H., Penninx R.: Research-Policy Dialogues on Migrant Integration in Europe: A Conceptual Framework and Key Questions. In: Integrating Immigrants in Europe: Research-Policy Dialogues. Eds. P. Scholten, H. Entzinger, R. Penninx, S. Verbeek. Dordrecht 2015.

Scholten P.: Framing Immigrant Integration: Dutch Research-Policy Dialogues in Comparative Perspective. Amsterdam 2011.

Stefańska R., Szulecka M.: "Pragmatycznie, a nie ideologicznie” - o polityce migracyjnej Polski. "Biuletyn Migracyjny” 2016, nr 55.

Surel Y.: The Role of Cognitive and Normative Frames in Policy-making. "Journal of European Public Policy" 2000, No 7, Issue 4.

Szarfenberg R.: Ewaluacja i analiza polityki spolecznej. W: Polityka spoleczna. Podręcznik akademicki. Red. G. Firlit-Fresnak, M. Szylko-Skoczny. Warszawa 2008.

Treaty of Lisbon Amending the Treaty on European Union and the Treaty Establishing the European Community (2007/C 306/01) - https://eur-lex.europa.eu/ legal-content/PL/TXT/HTML/?uri=CELEX:12007L/TXT\&from=EN (accessed: 6.02.2019).

Turnpenny J., Radaelli C.M., Jordan A., Jacob K.: The Policy and Politics of Policy Appraisal: Emerging Trends and New Directions. "Journal of European Public Policy" 2009, No 16, Issue 4.

ZybalA A.: Polityki publiczne. Warszawa 2012.

Agnieszka Kulesa is a PhD student at the Warsaw School of Economics and an economist in the Centre for Social and Economic Research (CASE). Her scientific interests focus on the issues related to international migration and the labour market. 